\title{
ABET accreditation for optical and photonics engineering: the why and how
}

Kathleen Robinson, Barry Shoop

Kathleen B. Robinson, Barry L. Shoop, "ABET accreditation for optical and photonics engineering: the why and how," Proc. SPIE 9793, Education and Training in Optics and Photonics: ETOP 2015, 97932L (8 October 2015); doi: $10.1117 / 12.2223228$

Event: Education and Training in Optics and Photonics: ETOP 2015, 2015, Bordeaux, France 


\title{
ABET accreditation for optical and photonics engineering: The why and how
}

\author{
Kathleen B. Robinson ${ }^{\mathrm{a}}$ and Barry L. Shoop ${ }^{\mathrm{b}}$ \\ ${ }^{a}$ SPIE, Bellingham, WA 98227; ${ }^{b}$ Department of Electrical Engineering and Computer Science, U.S. \\ Military Academy, West Point, NY 10996;
}

\begin{abstract}
The authors have recently been involved with ABET (formerly the Accreditation Board for Engineering and Technology) and multiple professional societies, educational institutions and industry to develop program criteria for the accreditation of optical and photonic engineering programs at the undergraduate and masters level. These collaborative efforts have resulted in the first published criteria for university programs in optics and photonics. We will discuss the motivation for seeking membership in ABET, who ABET is and what it does, the process used to develop program criteria and the value of accreditation to both students and industry. This presentation will also include a segment addressing the steps involved for those optics and photonics engineering programs seeking ABET accreditation and resources that are available to assist them.
\end{abstract}

ABET has a long history of global engagement with the overarching goal of promoting and improving the quality of technical education worldwide. We will also discuss ABET's international activities and how they support ABET's mission of providing world leadership in assuring quality in applied science, computing, engineering, and engineering technology education.

Keywords: ABET, accreditation, program criteria, engineering education

\section{WHY ABET?}

Since the very first ETOP meeting in 1988 the subject of quality control and the consistency of optics programs has been a topic of discussion. In one of the earliest ETOP papers Professor R. Barry Johnson from the Center for Applied Optics at the University of Alabama Huntsville suggests the eventual need for ABET accreditation. ${ }^{1}$ And in fact the keynote address delivered at that initial ETOP conference by the esteemed Brian J. Thompson from the University of Rochester defines one of the challenges of optics as, "that of defining our field and designing the program content for each educational level...... What do we teach, to whom, for what purpose and to fill what need?" and in his conclusion he suggests the need to evaluate our degree programs in light of the needs of industry and government. ${ }^{2}$

ABET, the Accreditation Board for Engineering and Technology was created in 1934 with the mission to assure confidence in the career preparation of professionals in applied science, computing, engineering and engineering technology education programs. Quality control and curriculum development in light of industry needs are the reason ABET was created and currently accredits more than 3,400 programs worldwide. ${ }^{3}$

\section{THE VALUE OF ACCREDITATION}

ABET accreditation provides assurance that a collegiate program has met standards essential for preparing graduates to enter and succeed in their respective field. Graduation from an ABET-accredited program ensures that individuals have a solid educational foundation in their area of study and have received the training and skills necessary to perform the work required in their position, to lead innovation, develop emerging technologies, and to ensure the welfare and safety needs of the public are met.

Education and Training in Optics and Photonics: ETOP 2015, edited by Eric Cormier, Laurent Sarger Proc. of SPIE Vol. 9793, 97932L · C 2015 SPIE, IEEE, OSA, ICO · doi: 10.1117/12.2223228 
Why does accreditation matter to students? It verifies that the student's education meets the global standard for technical education. It enhances employment opportunities and supports entry into a technical profession through licensure, registration, and certification - all of which usually require graduation from an ABET-accredited program. And it establishes a student's eligibility for many federal student loans, grants, or scholarships.

For programs and institutions the accreditation process yields data and insights that can be used to develop curricula in response to the needs of industry and assures satisfactory preparation of students to apply what they have learned. The organizations and individuals involved in accreditation are knowledgeable about their profession's workforce needs and review academic programs to ensure they provide the technical and professional skills graduates need to succeed. ${ }^{4}$

Ten years ago, this need for ABET accreditation was outlined by Charles Joenathan, Robert Bunch and Sergio Granieri in a paper presented at ETOP 2005. The authors, from Rose-Hulman Institute of Technology (one of the early ABET accredited optics program) stated, "The multidisciplinary field of optics in the undergraduate curriculum is facing revolutionary changes as optical techniques become the standard tools for industrial inspection and as optical components become standard items in consumer products. As educators, we are faced with the task of designing a curriculum to meet the growing needs of the market trend. This requires the need to improve the curriculum from the traditional science course sequence and match the need for more applied and engineering nature of the courses. With this transition we initiated the process of seeking accreditation for this optical engineering program through the Accreditation Board of Engineering and Technology (ABET). The intent of the optical engineering program at Rose-Hulman is to prepare students for the practice of engineering at a professional level." 5

And for industry and government ABET accreditation ensures that graduates are prepared to enter their profession and contribute to the community. It provides opportunities for the industry to guide the educational process to reflect current and future needs and enhances the mobility of professionals. ${ }^{6}$

\section{HOW DID THIS COME ABOUT?}

Though there was much discussion over the years, it was not until 2004 when Charles Joenathan and Robert Bunch from Rose-Hulman Institute of Technology sent a letter to SPIE pointing out the growing need for accredited programs in optics and photonics and encouraging SPIE to pursue membership in ABET that the wheels started to turn. Even then Society leadership spent two years examining the pros and cons of ABET accreditation before deciding to pursue this path (it is no small task from anyone's perspective) and then another year was spent preparing the application, and it took another year for ABET to approve and ratify that application. It wasn't until fall of 2010 that SPIE became a full member of ABET and was named co-lead society, along with the IEEE, for programs in optical and photonic engineering. At that time the SPIE Board of Directors elected Professor Barry Shoop of West Point to be their first representative director to the ABET Board and to help lead the way.

What SPIE's membership in ABET and their designation as a co-lead society for optical and photonic programs meant was that SPIE would bring together stakeholders to develop program criteria specific to the field and would select, train and assign the ABET Program Evaluators responsible for determining accreditation for those programs in the field that sought it.

In January of 2011, at the Photonics West meeting, SPIE assembled deans, chairs and department heads from institutions with ABET accredited optics programs and those likely to seek accreditation along with representatives from SPIE, IEEE and OSA. It was then that work finally began on the program criteria specific to optical and photonic engineering programs. See Table 1 below for a list of individuals present and programs represented at that first meeting. To quote Professor Shoop, chair of this first committee, "The objectives of the meeting were to: (1) inform ABET accredited programs and potential programs of SPIE's new role in ABET, (2) understand optical and photonic engineering program accreditation needs, (3) solicit input on and begin first-draft of optics and photonics program criteria, (4) solicit volunteers to assist with the development of program-specific criteria, (5) determine who needs to be involved in the process, and to (6) create a timeline, including steps and milestones for proposing optics/photonics criteria to ABET."7

At the conclusion of this meeting a plan for moving forward had been mapped out, the participation of stakeholders had been secured and a timeline was agreed upon. In addition, a draft of the program criteria specific to optics and photonics 
engineering was begun. The group present at this initial meeting went on to become the ABET Academic Advisory Group.

Table 1. Participants at the first meeting of ABET stakeholders for optics and photonics programs

\begin{tabular}{|l|l|l|l|l|}
\hline \multicolumn{4}{|c|}{ Participants in January 2011 Meeting } \\
\hline Barry Shoop (Chair) & $\begin{array}{l}\text { U.S. Military Academy, West } \\
\text { Point }\end{array}$ & Charles Joenathan & $\begin{array}{l}\text { Rose-Hulman Institute of } \\
\text { Technology }\end{array}$ \\
\hline $\begin{array}{l}\text { James Wyant } \\
\text { Carl Maes } \\
\text { Mike Nofzier }\end{array}$ & University of Arizona & $\begin{array}{l}\text { Andrew Berger } \\
\text { Jannick Rolland } \\
\text { Wayne Knox (OSA) }\end{array}$ & University of Rochester \\
\hline $\begin{array}{l}\text { Bahaa Saleh } \\
\text { David Hagan }\end{array}$ & University of Central Florida & $\begin{array}{l}\text { Kyo Song } \\
\text { Patricia Mead }\end{array}$ & Norfolk State University \\
\hline Robert Lindquist & University of Alabama Huntsville & Eric Johnson & University of North Carolina \\
\hline Scott Teare & $\begin{array}{l}\text { New Mexico Institute of Mining } \\
\text { and Technology }\end{array}$ & $\begin{array}{l}\text { Theodore Bickart } \\
\text { (IEEE) }\end{array}$ & Colorado School of Mines \\
\hline Hector Baldis & University of California Davis & Wei Chen & University of Central Oklahoma \\
\hline Kevin Harding & GE Global Research & Ralph James & Brookhaven National Lab. \\
\hline Eugene Arthurs & SPIE & Kathleen Robinson & SPIE \\
\hline
\end{tabular}

In addition to the input of academia, it was clear that input from industry was critical to the development of program criteria. SPIE staff assembled representatives from a dozen leading companies to provide input on the needs of industry. This Industry Advisory group was made up of individuals selected from major companies who consistently employ optical and photonic engineers, and who are familiar with the kind of background needed for engineers to succeed in the field. See Table 2 below for a list of those individuals and the companies represented.

Table 2. Members of ABET Industry Advisory Group and companies represented

\begin{tabular}{|l|l|l|l|}
\hline \multicolumn{5}{|c|}{ ABET Industry Advisory Group } \\
\hline $\begin{array}{l}\text { Ray Haynes } \\
\text { John Brock }\end{array}$ & $\begin{array}{l}\text { Leonard Chen } \\
\text { Richard Juergens }\end{array}$ & Raytheon \\
\hline $\begin{array}{l}\text { Ray Johnson } \\
\text { Jeffrey Wilcox }\end{array}$ & Lockheed Martin & $\begin{array}{l}\text { Walt Bosenberg } \\
\text { Tony DeMaria }\end{array}$ & Coherent \\
\hline Kevin Harding & GE Global & Kevin Tice & Melles Griot \\
\hline Waguih S. Ishak & Corning & Ken Kaufmann & Hamamatsu \\
\hline Fred Van Milligen & JDS Uniphase & Robert Edmund & Edmund Scientific \\
\hline Ray Morrison & $\begin{array}{l}\text { Associates for Continuing } \\
\text { Education in Technology and } \\
\text { Science }\end{array}$ & & \\
\hline
\end{tabular}

This group worked together via email and teleconference, refining the original program criteria drafted by the Academic Advisory Committee in light of the needs of industry.

It was also in spring of 2011 that the first Program Evaluators (PEVs) for optical and photonic programs were trained and programs could actually request them to evaluate their programs. Two optical and photonic programs were evaluated that first year with PEVs requested from SPIE.

By the late summer of 2011 the Academic Advisory Committee and the Industry Advisory Committee had consensus on the draft criteria for optical and photonic engineering programs and this draft was presented to SPIE's Education Committee and the IEEE's Committee on Engineering Accreditation Activities for approval from the co-lead societies. Once that approval had been obtained the draft criteria were sent off to the ABET Engineering Accreditation 
Commission (EAC) and the ABET Board of Directors in January of 2012 to be subjected to their approval process. After EAC and ABET Board approval was obtained the draft criteria were posted for one year for public review and comment. At the end of that year (2013) the ABET board reviewed the comments received, determined the draft criteria were appropriate and endorsed by the community and approved them for the following accreditation cycle (2014-15).

Below are the program criteria for optical, photonic, and similarly named engineering programs as they were originally published and as they remain today.

\section{PROGRAM CRITERIA FOR OPTICAL, PHOTONIC, AND SIMILARLY NAMED ENGINEERING PROGRAMS}

\section{Co-Lead Societies: SPIE - The International Society for Optical Engineering and the IEEE - Institute of Electrical and Electronics Engineers}

These program criteria apply to all engineering programs that include "optical", "photonic", or similar modifiers in their titles.

\section{Curriculum}

The structure of the curriculum must provide both breadth and depth across the range of engineering topics implied by the title of the program.

The curriculum must prepare students to have knowledge of and appropriate laboratory experience in: geometrical optics, physical optics, optical materials and optical and/or photonic devices and systems.

The curriculum must prepare students to apply principles of engineering, basic sciences, mathematics (such as multivariable calculus, differential equations, linear algebra, complex variables, and probability and statistics) to modeling, analyzing, designing, and realizing optical and/or photonic devices and systems.

Faculty

For primarily design courses, faculty members must be qualified by virtue of design experience as well as subject matter knowledge.

Once these program criteria were established it was time for institutions and programs to apply them and to be evaluated in light of them. This requires that programs prepare their content and processes in accordance with the specific program criteria, plus the eight core criteria common to all engineering programs and be evaluated within the ABET accreditation process.

\section{THE HOW FOR PROGRAMS/INSTITUTIONS}

Initially programs must determine if they are eligible for ABET accreditation and that is done in reference to six eligibility requirements shown below that are outlined on the ABET website.

Program Eligibility Requirements:

1. Meet ABET's Definition of a Program. Both the program seeking accreditation and the institution in which it is housed must meet eligibility requirements for ABET accreditation. ABET accredits programs only - not degrees, departments, colleges, institutions, or individuals. A program is defined as an integrated, organized experience that culminates in the awarding of a degree. The program will have program educational objectives, student outcomes, a curriculum, faculty, and facilities, as described in the accreditation criteria. ABET does not accredit certification, training, or doctoral programs. 
2. Be Housed in a Degree Granting Institution. ABET accepts Requests for Evaluation (RFE) from postsecondary programs offered by degree-granting institutions with verifiable and recognized governmental, national, or regional authority to confer degrees.

3. Have at Least One Graduate. Programs requesting an initial accreditation review must have at least one graduate prior to the academic year when the on-site review occurs.

4. Name Must Meet ABET Requirements. The name of a program seeking accreditation must be descriptive of the program's content and be stated exactly the same way on the graduate's transcript and in the institution's literature.

Programs outside the U.S. where English is not the native language, must provide the program's name both in English and in the native language(s). An institution may not use the same program name to identify both an ABET-accredited program and a program that is not ABET-accredited.

5. Be Accreditable Under at Least One ABET Accreditation Commission. Each program seeking accreditation will be assigned to a specific commission or commissions based upon the literal name of the program:

- Applied Science Accreditation Commission (ASAC). Programs accredited by ASAC are those leading to professional practice utilizing science, mathematics, and engineering concepts as a foundation for disciplinespecific practice.

- Computing Accreditation Commission (CAC). Programs accredited by CAC are those leading to professional practice across the broad spectrum of computing, computational, information, and informatics disciplines.

- Engineering Accreditation Commission (EAC). Programs accredited by EAC are those leading to the professional practice of engineering. All engineering programs requesting ABET review must include the word "engineering" in the program name.

- Engineering Technology Accreditation Commission (ETAC). Programs accredited by ETAC prepare baccalaureate degree graduates for careers as engineering technologists and prepare associate degree graduates for careers as engineering technicians. All ETAC programs requesting ABET review must include the word "technology" in the program name, but the phrase "engineering technology" is preferred.

6. Some Programs Must Undergo a Readiness Review. ABET requires a preliminary Self-Study Report from all programs seeking initial accreditation, if the institution has no currently ABET-accredited programs in that same commission. After a review of this preliminary Self-Study Report, which is called the Readiness Review, ABET will determine whether or not an institution is ready to submit a formal Request for Evaluation (RFE) for that program. ${ }^{8}$

Once a program determines itself to be eligible and decides that it wants to be evaluated then it must make a Request for Evaluation (RFE) by January 31 of that year. This begins the ABET Accreditation Process, which is a 2-Year Process.

Below is a timeline showing the steps involved as given on the ABET website.

Step 1: Complete the Readiness Review (if required) by November 1

- Collect samples of student work, syllabi, textbooks, and sample assignments.

- Develop a Preliminary Self-Study Report for each program. This is required by November 1 of the year before a program plans to submit a Request for Evaluation (RFE) as part of its Readiness Review.

Step 2: Submit the Request for Evaluation (RFE) by January 31 (Year 1)

- ABET invoices the institution at this time for the On-Site Visit, sets a visit date, and forms a review team between April and May.

Step 3: Complete and submit Self-Study Report by July 1 (Year 1)

- A review team is assigned to the program and begins reviewing the Self-Study Report.

- ABET Institutional Representatives Day. A program's institutional representative is invited to meet its review team chair at this annual event, held in Baltimore, MD, in July. 
Step 4: The On-Site Visit takes place September - December (year 1)

- Institutions begin planning and preparation for an On-Site Visit months in advance. They finalize the visit schedule, arrange student and faculty interviews, and, finally, set up rooms with display materials for the review team.

- On-Site Visits take place in the fall and typically last three days (usually Sunday through Tuesday). Visits include a review of materials; interviews with students, faculty, staff, and administrators; and concludes with an exit meeting, when the team conveys its findings.

Step 5: Due Process and the Accreditation Decision (end of year 1 and year 2)

1 Week after the visit: An institution can provide the review team with any errors of fact resulting from the exit meeting.

2-3 months after the visit: An institution receives the Draft Statement, a formal communication of the review team's findings.

3-4 months after the visit: During a 30-Day Due Process period an institution may respond to any shortcomings identified in the Draft Statement.

July Year 2: The ABET commissions meet to decide Accreditation Actions in July. At this meeting each program's accreditation is discussed and decided.

By August 31 (year 2): Each program is formally notified of the accreditation action via the Final Statement to the institution. ${ }^{9}$

ABET Accreditation Resources - Successful accreditation requires an understanding of the ABET accreditation requirements and processes and the most current criteria. There are a number of resources available to assist in this. ABET regularly hosts symposia, workshops and webinars that provide insights on the accreditation process, criteria, assessment and continuous improvement. ${ }^{10}$

A particularly valuable approach, from an institution's perspective, is to have at least one faculty member volunteer to be an ABET Program Evaluator (PEV). PEVs do the hands-on work of accrediting over 3,400 programs at nearly 700 institutions in 28 countries, know the process very well, and so are in a good position to guide the ABET process in their own schools. In 2015, ABET has more than 2,200 volunteer PEVs from industry, government and academia. PEVs receive the most up-to-date training and have first-hand insights about the ABET accreditation process and bring that to their respective program. SPIE has trained $12 \mathrm{PEVs}$ for optical and photonic programs, all from institutions with ABET accredited programs and involved in their own institution's accreditation process.

In addition, SPIE is working on the development of a workshop that will be presented at least once a year for individuals involved in programs going through the ABET accreditation process or who are interested in learning more about it.

\section{ABET'S INTERNATIONAL ACTIVITIES}

ABET also takes an active role in the global quality assurance process for technical education programs through numerous agreements with organizations worldwide. These include Mutual Recognition Agreements (MRAs) and Memoranda of Understanding (MOUs).

ABET's Global Council receives frequent requests from organizations outside the United States, seeking technical assistance in developing or gaining recognition for their accreditation systems. ABET's services to help higher education agencies or organizations outside the U.S. in developing quality assurance processes are formalized under Memoranda of Understanding (MOUs). Often the underlying goal of these requests is to prepare an accrediting agency or higher education authority for entrance into an international MRA, such as the Seoul, Washington, Dublin, or Sydney accords.

\section{Mutual Recognition Agreements (MRA)}

Mutual Recognition Agreements (MRAs), often known as "accords," are non-governmental agreements among organizations that accredit academic degree programs. These agreements recognize the substantial equivalency of participating organizations' accreditation processes and their graduates' preparedness to begin professional practice at 
the entry level. Substantial equivalency means that the accreditation systems have comparable standards, outcomes, and processes, even though they may not be identical. ${ }^{11}$

ABET is a signatory to five MRAs:

- The bilateral agreement between Engineers Canada and ABET (for engineering programs)

- The multilateral Washington Accord (for engineering programs)

- The multilateral Seoul Accord (for computing programs)

- The multilateral Sydney Accord (for bachelor degree-level engineering technology programs)

- The multilateral Dublin Accord (for associate degree-level engineering technician programs)

Memoranda of Understanding (MOUs)

ABET uses Memoranda of Understanding (MOUs) and Letters of Intent (LOI) to formalize and structure their collaborative efforts with peer accrediting agencies outside the United States during their developmental period. Unlike a Mutual Recognition Agreement, an MOU does not recognize the "substantial equivalency" of an organization's accreditation processes or graduates' preparedness to begin professional practice. Activities through an MOU (or LOI) may include the sharing of best practices, assisting organizations in the development of accreditation processes, and providing training workshops for staff and volunteers of peer organizations. ${ }^{12}$

ABET currently maintains the following MOUs and LOIs:

- Argentina - Comisión Nacional de Evaluación y Acreditación Universitaria

- Caribbean Region - Greater Caribbean Regional Engineering Accreditation System

- Central America - Agencia Centroamericana de Acreditación de Programas de Arquitectura y de Ingenieria

- Chile - Acredita CI

- China - China Association of Science and Technology

- Egypt - National Authority for Quality Assurance and Accreditation in Education

- France - Commission des Titres D'Ingenieur

- Germany - ASIIN e.V.

- Israel - Council for Higher Education

- Japan - Accreditation Board for Engineering Education

- Korea - Accreditation Board for Engineering Education

- Peru - Instituto de Calidad y Acreditación de Programas de Computación, Ingeniería y Tecnología

- Portugal - Ordem dos Engenheiros

- Spain - Agencia de Calidad, Acreditación y Prospectiva de las Universidades de Madrid

- $\quad$ Chinese Taipei - IEET

- Uruguay - UNESCO Regional Office for Science and Technology for Latin America and Caribbean

- Western Hemisphere Initiative (Mexico and Canada) - Consejo de Acreditación de la Enseñanza de la Ingeniería and Canadian Engineering Accreditation Board (CEAB) of the Canadian Council of Professional Engineers

- Letter of Intent - Ministry of Higher Education, Ukraine

ABET respects the autonomy of each nation's higher education quality assurance organization and does not interfere with existing or future accreditation activities in countries outside the United States. ABET will conduct accreditation reviews outside the United States only with explicit permission from all applicable national education authorities in that program's country or region. In order to seek accreditation by ABET, programs outside of the U.S. must have each appropriate education authority, recognition, or accreditation agency complete a Request for Approval form to be submitted with the formal Request for Evaluation. ${ }^{13}$

The ABET accreditation process for programs located outside of the United States (U.S.) is identical to the accreditation process for programs within the U.S. ${ }^{14}$

ABET's global activities are seen to be consistent with the priorities of its constituents. Students and young professionals are increasingly multicultural and mobile and need for their credentials to be transportable. ABET's member societies nearly all have international membership and chapters who understand the importance of accreditation and are looking for resources in that area. Institutions of higher education are trending toward the establishment of 
international campuses and offering distance learning. And much of industry's success today is based on a global presence with branches and employees all over the world. ${ }^{15}$

In its desire to be responsive to its constituency ABET is engaged globally. As of October 2014 ABET accredited 3,466 programs at 698 colleges and universities in 28 countries. ABET's uniform accreditation criteria, policies and procedures were used for all visits, regardless of location, to ensure consistency and quality.

\section{CONCLUSION}

In conclusion the authors would like to note the continued growth of optical and photonic technologies and the increase of its applications throughout our world. As this expansion continues (both numerically and geographically) the need for consistently trained, qualified graduates will expand accordingly, as will the need for accreditation and the standards and quality that ABET represents. Our work will continue.

We would also like to take this opportunity to thank all of the individuals who gave of their time and energy to move this effort forward. As with any significant endeavor, this was not achieved by one person or one group of individuals. It was a cooperative venture, undertaken by those who saw the importance of accreditation to move the discipline forward. The discipline of optics and photonics and those of us who follow it owe an enormous debt of gratitude to these individuals for their vision and hard work.

[1] Johnson, R. Barry, “Quality Control of Academic Optics Programs?” Proc. SPIE Vol. 978, 136-139 (1988).

[2] Thompson, Brian J., "Education in optics - challenges at hand," Proc. SPIE Vol. 978, 1-9 (1988).

[3] ABET website, Accreditation, http://www.abet.org/accreditation/

[4] Ibid.

[5] Joenathan, C., Bunch R., Granieri, S. "Optical engineering education with curriculum mapping for ABET

accreditation," Proceedings of ETOP, 249-264 (2005).

[6] ABET website, Accreditation, http://www.abet.org/accreditation/

[7] Shoop, Barry, Robinson, Kathleen, "ABET accreditation and optics and photonics engineering: an association whose time has come," Proc. SPIE Vol. 8481, 848107, (2012).

[8] ABET website, Accreditation, http://www.abet.org/accreditation/get-accredited-2/get-accredited-step-by-step/

[9] Ibid.

[10] ABET Website, http://www.abet.org/accreditation/new-to-accreditation/help-with-the-process/

[11] ABET website, Global Presence, http://www.abet.org/global-presence/

[12] Ibid.

[13] Ibid.

[14] Ibid.

[15] Ibid. 